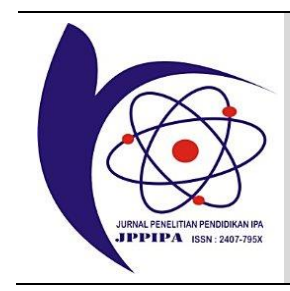

\title{
Application of Contextual Teaching and Learning (CTL) Learning Strategies on Metacognitive Ability and Leaarning Outcomes in Immune System Materials
}

\author{
Maulinda Yani $^{1 *}$, Safrida ${ }^{1}$, Muhibuddin ${ }^{1}$ \\ ${ }^{1}$ Biology Education, Faculty of Teacher Training, Syiah Kuala University, Banda Aceh, Indonesia.
}

DOI: $10.29303 /$ jppipa.v7i4.765

\section{Article Info}

Received : May 30th, 2021

Revised : August 15th, 2021

Accepted: October 3rd, 2021

\begin{abstract}
This study aims to determine the differences in metacognitive abilities and student learning outcomes after applying Contextual Teaching and Learning (CTL) learning strategies in the experimental class and the control class on the material of the immune system. The research method used is an experimental method with a pretest-posttest control group research design. The research subjects were 125 students at SMAN 2 Lhokseumawe. The parameters measured were metacognitive ability using a questionnaire and learning outcomes using the multiple-choice type test objective. Data was collected through pretest and posttest on metacognitive abilities, and learning outcomes were analyzed by parametric statistical tests using independent sample t-test. The metacognitive t-test on the score strongly agrees with the students in the experimental class and the control class, namely $t_{\text {count }}(6.14)>t_{\text {table }}(1.65)$ significantly different. Metacognitive $t$-test on scores quite agrees with students in the experimental class and control class, namely $t_{\text {count }}(0.61)$ $<t_{\text {table }}(1.65)$ not significantly different. The metacognitive $t$-test on the score slightly agrees with the students in the experimental class and the control class, namely $t_{\text {count }}(10.07)>t_{\text {table }}(1.65)$ significantly different. The metacognitive t-test on the students' disagreeing scores in the experimental class and control class, namely $t_{\text {count }}(14.40)>t_{\text {table }}(1.65)$, was significantly different. The results showed differences in the application of CTL learning strategies to metacognitive abilities and learning outcomes between the experimental and control classes. It can be concluded that there are differences in metacognitive abilities and learning outcomes between the experimental class and the control class after the application of the CTL learning strategy to students at SMAN 2 Lhokseumawe on the subject of the immune system.
\end{abstract}

Keywords: Contextual Teaching and Learning (CTL); Metacognitive; Learning Outcomes

Citation: Yani, M., Safrida, S., \& Muhibuddin, M. (2021). Application of Contextual Teaching and Learning (CTL) Learning Strategies on Metacognitive Ability and Leaarning Outcomes in Immune System Materials. Jurnal Penelitian Pendidikan IPA, 7(4), 576-581. doi:https://doi.org/10.29303/jppipa.v7i4.765

\section{Introduction}

Metacognition is one of the essential aspects of the learning process. Through this metacognition, students can organize themselves in planning their learning. The application of the learning process as a metacognitive thinking strategy has a significant effect on the learning outcomes of students who get better grades (Septiana et al., 2013).

Students will feel impressed with learning if in the learning process, students get good results from their understanding and discoveries, especially on immune system material. Learning like this brings students to a learning experience. A good learning experience will make students want to experience it again to participate in the learning process actively.

Data on the average value of the results of the National Examination (UN) Learning biology shows unsatisfactory results, especially at SMA Negeri 2 Lhokseumawe in (2017) the average value only reached 38.51 , in (2018) the average score reached 38.01 while in (2019) the average value was 41.60 (Anonymous, 2019). 
In addition, based on the results of preliminary studies that have been conducted on teachers at SMAN 2 Lhokseumawe, the material of the immune system is complex for students to understand because the science is so broad and abstract that students experience problems in the process of understanding metacognitive abilities.

Students have not achieved maximum results. The Data of Class XI 2019 shows that out of 125 students there are $60 \%$ of students have not reached the Minimum Completeness Criteria (MCC). Therefore, to overcome this problem, it is necessary to find a solution for the learning process so that understanding of biological material, especially the material of the immune system, can be improved. Therefore, to overcome this problem, it is necessary to find a solution.

One solution is to innovate learning strategies. One learning strategy that meets these criteria is the Contextual Teaching and Learning (CTL) learning strategy. With CTL, students are trained to optimally complete tasks or questions related to a problem to achieve learning objectives, which can later measure students' metacognition to obtain better learning outcomes.

Several learning research studies on CTL have been conducted (Servitri, 2017; Muhajir and Rohaeti, 2015; Musriliani et al., 2015). The results of the study stated that learning with the CTL approach was categorized as a theoretical strategy. Science learning materials that are abstract theoretical, and academic, not related to the problems students face every day in the family, community, and natural environment, become easier to understand with the CTL. After applying CTL learning, the criteria for effective learning are achieved with the success of learning outcomes indicators (cognitive) better.

The results of this study only reveal the effect of CTL on learning outcomes, while the application of CTL on metacognitive abilities and learning outcomes has not been studied. Therefore, it is necessary to conduct research in order to achieve learning outcomes that are in line with expectations. It takes the creativity of researchers in carrying out learning activities, so that it is necessary to "Application of CTL Learning Strategies on Metacognitive and Learning Outcomes."

\section{Method}

The methods in this study use experimental methods with pre-posttest control group research designs. Experimental classroom students and control class students are determined by random sampling. The experimental group consisted of two classes. Both groups were given treatment in the form of Contextual
Teaching and Learning (CTL) learning strategies, while the control group consisted of two classes that were also given the usual treatment taught in that class.

The approach used in this research is quantitative. This research was conducted at SMA Negeri 2, which is located on Stadium Street, Tunas Bangsa Mon Geudong, Banda Sakti District, Lhokseumawe City. The population in this study were all students at SMA Negeri 2 Lhokseumawe, totaling 592. The sample taken was class IX science students, totaling 125 students. Metacognitive ability was measured using an instrument in the form of a questionnaire, how to collect data by being given a questionnaire before and after the learning process.

Learning outcomes data were collected through pretest and posttest activities. Pretest data were used to measure the initial abilities of students in the experimental class and control class. Then the posttest data was used to measure the final stage ability of students in the experimental class and control class. The data was obtained in the form of numbers in the form of scores. The data is analyzed first by tabulating. The metacognitive ability questionnaire data was calculated the average score using the percentage calculation formula. The data obtained in the study are quantitative and qualitative data. The data are in the form of pretestposttest results and also observations. After the data has been collected, before the t-test is carried out, the normality test and homogeneity test are carried out on the pretest score and posttest score data.

\section{Result and Discussion}

\section{Metacognitive Ability of Learners}

A questionnaire sheet measures the metacognitive ability of students. The average results of students' metacognitive thinking abilities in the experimental class and control class can be seen in Figure 1.

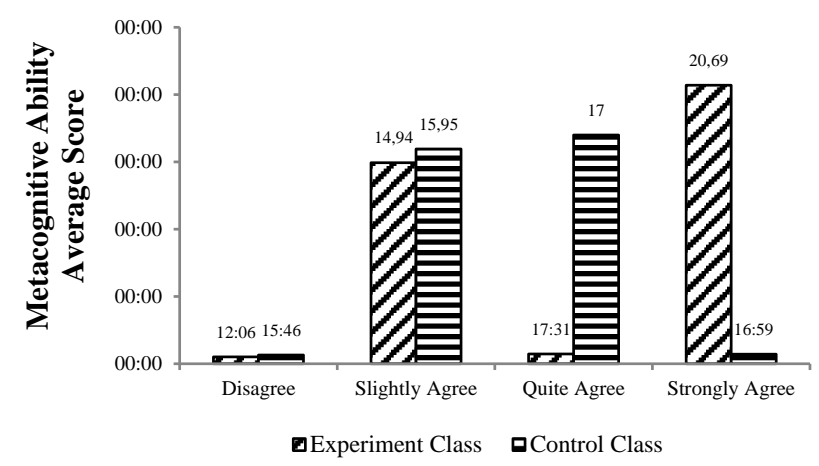

Figure 1. Average Metacognitive Ability Score of Individual Students in Experiment Class and Control Class 
Based on Figure 1 shows that the component strongly agrees the experimental class is higher than the control class. The average score of metacognitive ability in the experimental class was $20.69 \%$ with strongly agreed criteria, while in the control class the average score of metacognitive ability was only $16.59 \%$.

Based on the results of the metacognitive average difference test, it was obtained that the metacognitive thinking ability of students in experimental and control classes was significantly different. This means that the overall metacognitive thinking skills of experimental classroom students taught by applying CTL learning strategies to metacognitive are better than control classes whose learning is conventional.

The data reached the top five categories in the instrument, namely the fear of students in the learning process who initially did not dare after being treated with the CTL learning strategy, students tended to be bolder and no longer worried about being wrong in answering, and worried about solving a given problem researcher.

The students' metacognitive ability (Figure 1) shows that there is a difference in the average score in the control class and the experimental class. The experimental class using the CTL learning strategy on students' metacognitive abilities got a high percentage, especially the score strongly agrees compared to the control class. The percentage score that has been measured based on the criteria on the questionnaire sheet that has been given to the control class has no significant effect compared to the experimental class.

In this study, the students' metacognitive ability in terms of scores strongly agrees that the results obtained (Figure 1) show differences between the two classes. This means that students have been able to think better with the help of learning strategies that have been applied. The recapitulation of the metacognitive average difference test on the score quite agrees shows that the difference is not significant. While the score slightly agrees and the score disagrees, there is no significant difference.

The application of CTL learning strategies has a very important effect on metacognition because, during the learning process using CTL, students play an active role in various activities and seek information about the immune system material, then students also work together when completing group assignments, students also conduct a question and answer interactions when the learning process takes place. Therefore, providing students with a way in which they can monitor their own learning and thought processes can be something that is effective in helping them become better problem solvers and ultimately become better thinkers for any task, especially on immune system material. The application of CTL to metacognition can help students understand the material, solve problems they face, and improve critical thinking patterns. Then monitor progress in learning and simultaneously correct if any mistakes occur while understanding the concept.

This is in accordance with the research of Munir and Nur (2018), the initial results of students' ability to communicate in order to build cognitive development abilities tend to be better if in groups and less well if individually. Thus, the communication competence of students tends to be good, but the ability to think critically by building and developing ideas is good enough only for problems used in low-level languages.

In line with Novitasari and Ninit's (2015) research, metacognitive abilities are basically owned by every individual. At certain times, a person will reflect on his ability to learn and think and implement strategies to complete tasks or solve problems encountered in the learning process. However, someone does not realize that what is being done is a metacognitive activity. The level of metacognitive ability possessed by individuals differs from one another depending on the learning activities they undertake.

Meanwhile, according to Saputra and Andriyani (2018), the results of research that have been done that it can be seen that a person's metacognitive ability is influenced by the level of the subject's ability, here it appears that research subjects with high abilities can solve the given problems, this is because the subject has the concept or ability needed to complete the test so that the subject can compose and work to the end and carry out the overall metacognitive process.

The results showed that metacognitive awareness could be developed through cooperative learning. Students learn actively in the classroom by empowering their potential. The existence of the role of students to become tutors, in turn, has made their motivation higher (Yursal et al., 2016).

Metacognition is a form of cognition, or a level 2 or more thought process involving the control of cognitive activity. So, metacognition can be said as one's thinking about one's own thinking or one's cognition about one's own cognition (Schneider, 2010).

In addition, metacognition involves a person's knowledge and awareness of his own cognitive activity or everything related to his cognitive activity. Woolfolk and Anita (2009). In simple terms, metacognition is knowledge about the process of cognition. More specifically, metacognition is knowledge, awareness, and control over cognitive processes. Metacognition has a role as a form of cognitive representation based on monitoring and controlling based on cognitive representations.

Chi and Kurt (2010). Argued that metacognition is the ability to monitor the material being studied. Metacognitive abilities help students understand the 
material and solve the problems they face. Students who use metacognitive strategies well can be critical thinkers, good problem solvers, and good decision makers than students who don't use metacognitive strategies.

Metacognitive strengths are carried out by using three metacognitive questions aimed at students themselves when taking the problem-solving process, including comprehension questions, strategic questions, and connection questions. The application of an open problem-based metacognitive learning model can improve students' mathematical problem-solving skills. This increase is due to the application of a learning model that emphasizes student activities in mobilizing awareness and organizing their thoughts (Thayeb and Putri, 2017).

Students' metacognitive abilities are welldeveloped because they include metacognitive components, namely declarative, procedural, conditional, planning, information management strategies, comprehension monitoring, and evaluation. (Pujiank et al., 2016).

Mathematical problem solving is a complex mental process that requires visualization, imagination, manipulation, analysis, abstraction, and unification of ideas. To do this, students need to manage their thinking well by utilizing the knowledge they already have, controlling and reflecting on the process and results of their own thinking, and what they think can help solve problems (Pramono, 2017).

\section{Student Learning Outcomes}

Student learning outcomes were analyzed by obtaining data on the initial ability and final ability of the experimental group and the control group, as shown in Figure 2.

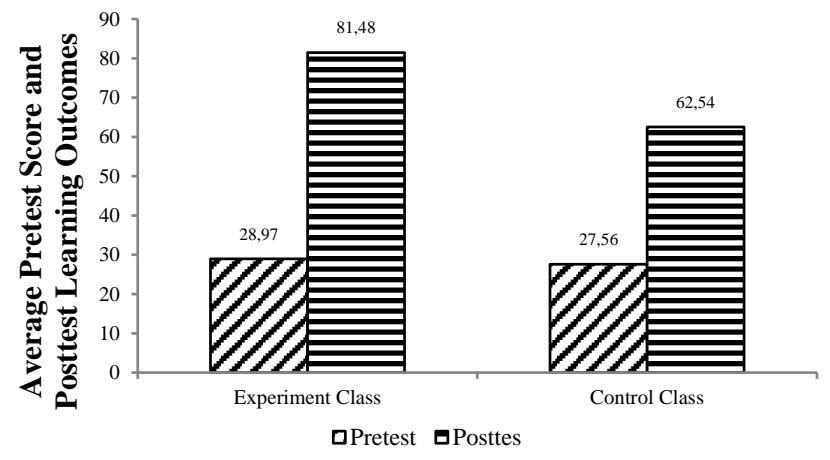

Figure 2. Average Pretest and Posttest Scores of Student Learning Outcomes between Experimental and Control Classes.

Figure 2 shows that the initial understanding of students as a whole does not show a significant difference. The average score of the students' initial abilities between the experimental and control classes was the same. After being treated with the application of the CTL learning strategy in the experimental class, the pretest score increased more than the posttest score for the control class. The average value of the pretest in the experimental class was 28.97, while the average value of the pretest in the control class was 27.56 . The posttest average value obtained in the experimental class is 81.48 , while the posttest average value in the control class is 62.54. This shows that there is a difference in the increase in the average value of student learning outcomes after using the application of the CTL learning strategy.

The CTL learning strategy applied in the experimental class makes students more active in expressing opinions during discussions and presentations because the CTL learning strategy is a learning concept when researchers associate the material with the real world into the classroom, especially on immune material that will encourage students later in solving the problem.

Learning is a process of seeking knowledge that occurs in a person through practice, learning, and so on so that changes occur in oneself. Changes in behavior are obtained from the results of the interaction of the individual with his environment. The influence caused by the interaction with the environment will permanently change overall behavior (Ningrum and Leonard, 2014).

Based on the hypothesis testing table on the pretest score, the score $t_{\text {count }}(0.73)<t_{\text {table }}(1.65)$, this shows that students who follow the CTL learning strategy on metacognitive show significantly better learning outcomes than students who follow conventional learning.

Based on the posttest test table, the score tcount (9.58)<ttable (1.65). It means that the CTL learning strategy on metacognitive shows increased learning outcomes. This can be seen in the posttest score that has been treated with the application of learning strategies CTL on metacognitive and student learning outcomes are significantly different.

The application of CTL learning strategies to learning outcomes during class learning is more meaningful. Students practice their own activities related to the existing immune system material so that students can understand it themselves, which can foster students' courage in expressing opinions about immune system material.

Student learning outcomes are better after being given the application of CTL strategies during the learning process. According to research Handini et al. (2016), the CTL model can improve student learning outcomes, make students more active, enthusiastic in learning, follow learning well, and can answer evaluation questions given by teachers quickly and accurately. Thus, it can be concluded that the hypothesis 
made can be accepted appropriately and according to the facts found.

The main contribution of this research is the new knowledge about the effectiveness of contextual teaching and learning (CTL) through the Connect, Experience, Apply, Cooperate and Transfer (REACT) strategy to improve students' critical thinking in writing. The results show that there is a significant difference in the mean scores between the pretest and posttest experimental learning after the CTL learning treatment is given (Nawas, 2018).

Based on the results of research by Kasmawati et al. (2017) descriptive analysis, in classes taught using the CTL (Contextual Teaching Learning) learning model, it shows that students' physics learning outcomes on average are very good (A) and good (B) predicates. Physics learning outcomes of students who have been taught with CTL learning (Contextual Teaching Learning) show that student learning outcomes dominate the predicate of very good (A) than students with a good predicate (B).

The CTL strategy is a learning process that aims to help students see meaning in the academic material they are studying by connecting academic subjects with the context in their daily lives, namely with the context of their personal, social, and cultural circumstances (Johnson, 2014).

Some characteristics of Contextual Teaching and Learning-based learning: 1. Cooperation, 2. Mutual support, 3. Fun, not boring, 4. Learning with passion, 5 . Integrated learning, 6. Using various sources, 7. Active students, 8. Sharing with friends, 9. Critical Students, and Creative Teachers, 10. Class walls \& hallways filled with student work, maps, pictures, articles, humor, etc. 11. Reports to parents do not only report cards, but the work of students, reports on practicum results, student essays, and so on (Trianto, 2010). While the approaches that can be used in contextual learning include ProblemBased learning, authentic Instruction, inquiry-Based Learning, project-based learning. work-Based Learning, service Learning (Service Learning), cooperative Learning (Komalasari, 2010).

The learning community is the creation of a learning environment in contextual learning (CTL). Learning communities are study groups that function as a communication forum to share experiences and ideas. Its application can form small groups or large groups and bring experts to class or study with other friends. Learning together with others is better than studying alone. The concept of a learning community suggests that learning outcomes are obtained from the collaboration with others. Learning outcomes are obtained from sharing experiences between friends, between groups, and between those who know and those who do not know (Suprijono, 2013).

\section{Conclusion}

Based on the discussion that has been described, it can be concluded that there are differences in the metacognitive abilities of students between the experimental class and the control class after applying the CTL learning strategy to the immune system material, and there are differences in student learning outcomes between the experimental class and the control class after applying the CTL learning strategy to the material immune system.

\section{Acknowledgments}

Alhamdulillah, thanks to the infinite, the writer prays to Allah SWT who has bestowed His grace and guidance, and I thank my parents and husband who have provided motivation, thesis supervisors, leaders, and staff of SMAN 2 Lhokseumawe for the support and material and enthusiasm never stop so that it becomes a strength for me while completing this article.

\section{References}

Chi, M. \& Kurt, V. L. (2010). Meta-Cognitive Strategi Instruction in Intellegent Tutoring Sistem: How, When, and Why. Journal Educational tchnology $\mathcal{E}$ Sociaty. 13(1): 25-39.

Handini, D., Gusrayani, D., \& Panjaitan, R. (2016). Penerapan Model Contextual Teaching and Learning Meningkatkan Hasil Belajar Siswa Kelas IV Pada Materi Gaya. Jurnal Pena Ilmiah, 1(1), 451460. doi:https://doi.org/10.23819/pi.v1i1.2974

Johnson, B. E. (2014). Contextual Teaching and Learning. Bandung: Kaifa.

Kasmawati, K., Latuconsina, N. K., \& Abrar, A. I. P. (2017). Pengaruh Model Pembelajaran Contextual Teaching and Learning (CTL) Terhadap Hasil Belajar. Jurnal Pendidikan Olahraga Dan Kesehatan, 5(2), 70-75. Retrieved from: http://journal.uinalauddin.ac.id/.../3482/3911. [Indonesian]

Komalasari, K. (2010). Pembelajaran Kontekstual (Konsep dan Aplikasi). Bandung: Refika Aditama. [Indonesian]

Muhajir, S., \& Rohaeti, E. (2015). Perbedaan Penerapan Model Pembelajaran STS dan CTL terhadap Literasi Sains dan Prestasi Belajar IPA. Jurnal Pendidikan Matematika dan Sains, 3(2), 143-155. doi:https://doi.org/10.21831/ipms.v6i2.10946 [Indonesian]

Munir \& Nur, R. H. (2018). The Development of English Learning Model Based on Contextual Teaching and Learning (CTL) In Junior High Schools. International Journal of Language Education. 2(1), 3139. doi:https:// doi.org/10.26858/ijole.v2i1.4326 
Musriliani, C., Marwan \& Iriantoansari, B. (2015). Pengaruh Pembelajaran Contextual teaching learning (CTL) Terhadap Kemampuan Koneksi Metamatis Siswa SMP Ditinjau dari Gender. Jurnal Didaktik Matematika. 2(2). doi: https://doi.org/10.24815/jp.v6i2.12727

[Indonesian]

Nawas, A. (2018). Contextual Teaching and Learning (CTL) Approach through REACT Strategies on Improving the Students' Critical Thinking in Writing. International Journal of Applied Management Science, 4, 46-49.

Novitasari \& Ninit. (2015). Kontribusi Motivasi Terhadap Kemampuan Metakognitif Mahasiswa Departemen Pendidikan Geografi FPIPS UPI. Skripsi: Bandung, Universitas Pendidikan Indonesia. [Indonesian]

Pramono. (2017). Aktivitas Metakognitif Siswa SMP dalam Pemecahan Masalah Matematika Berdasarkan Kemampuan Matematika. Jurnal Matematika Kreatif-Inovatif. 8(2): 125-133. doi: https://doi.org/10.15294/kreano.v8i2.6703 [Indonesian]

Pujiank, S., Jamaluddin. \& Hadiprayitno, G. (2016). Kemampuan Metakognisi Mahasiswa Program Studi Pendidikan Biologi Fkip Universitas Mataram. Jurnal Pendidikan: Teori, Penelitian, dan Pengembangan. 1(10): 54-64. doi: http://dx.doi.org/10.17977/jp.v1i10.7413 [Indonesian]

Saputra, N. N. \& Andriyani, R. (2018). Analisis Kemampuan Metakognitif Siswa SMA dalam Proses Pemecahan Masalah. Jurnal Pendidikan Matematika FKIP Univ. Muhammadiyah Metro. 7(3): 132-144. doi: http://dx.doi.org/10.24127/ajpm.v7i3.1403 [Indonesian]

Schneider, W. (2010). Metacognition, strategy use, \& instruction. New York, NY: the Guilford Press.

Septiana, K., Andreas, P. B. P. \& Wulan, C. (2013). Jurnal Belajar Strategi Metakognitif Pada Pembelajaran Sistem Imunitas. Unnes Journal of Biology Education. 2(1): 57-62. doi: https://doi.org/10.15294/jbe.v2i1.2608 [Indonesian]

Servitri, O. M. (2017). Pembelajaran Multimedia IPA dengan Model Contextual Teaching and Learning Untuk Meningkatkan Hasil Belajar Siswa. Mimbar Sekolah Dasar, 4(1), 1-8. doi: https://doi.org/10.53400/mimbar-sd.v4i1.6157. [Indonesian]

Suprijono, A. (2013). Cooperative Learning: Teori dan Aplikasi PAIKEM. Yogyakarta: Pustaka Pelajar. [Indonesian]
Thayeb, T. \& Putri, A. P. (2017). Kemampuan Metakognisi untuk Meningkatkan Keterampilan Pemecahan Masalah Matematika Siswa Kelas VIII B MTS Madani Alauddin Paopao Kabupaten Gowa. MaPan: Jurnal Matematika dan Pembelajaran. 5(1): 26-32. doi: https://doi.org/10.24252/mapan.2017v5n1a1 [Indonesian]

Trianto. (2010). Mendesain Model Pembelajaran InovatifProgresif. Jakarta: Kencana. [Indonesian]

Woolfolk \& Anita. (2009). Educational Psychology: Active Learning Edisi Kesepuluh Bagian Kedua. Yogyakarta: Pustaka Pelajar. [Indonesian]

Yursal., Muhibbuddin., \& Samingan. (2016). Pengaruh Penerapan Pembelajaran Peer Mediated Instruction and Intervention (PMII) Tipe ClassWide Peer Tutoring (CWPT) Terhadap Peningkatan Kesadaran Metakognitif pada Konsep Ekosistem di SMA Negeri 1 Paya Bakong. Jurnal EduBio Tropika. 4(2): 13-25. Retrieved from: http://jurnal.unsyiah.ac.id/JET/article/view/7 $\underline{132}$ [Indonesian] 